\title{
Article \\ Genome Sequence and Assessment of Safety and Potential Probiotic Traits of Lactobacillus johnsonii CNCM I-4884
}

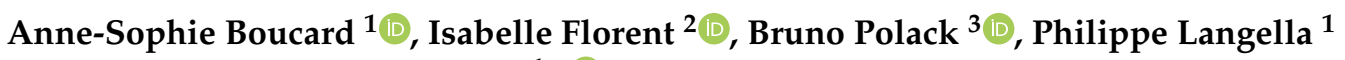 \\ and Luis G. Bermúdez-Humarán 1,*(D) \\ 1 INRAE, AgroParisTech, Micalis Institute, Université Paris-Saclay, 78350 Jouy-en-Josas, France; \\ Anne-Sophie.Boucard@inrae.fr (A.-S.B.); philippe.langella@inrae.fr (P.L.) \\ 2 UMR 7245, Muséum National d'Histoire Naturelle, Centre National de la Recherche Scientifique, \\ Sorbonne Universités, 75005 Paris, France; isabelle.florent@mnhn.fr \\ 3 Anses, INRAE, Ecole Nationale Vétérinaire d'Alfort, UMR BIPAR, Laboratoire de Santé Animale, \\ 94700 Maisons-Alfort, France; bruno.polack@vet-alfort.fr \\ * Correspondence: luis.bermudez@inrae.fr; Tel.: +33-1-3465-2463
}

Citation: Boucard, A.-S.; Florent, I.; Polack, B.; Langella, P.; BermúdezHumarán, L.G. Genome Sequence and Assessment of Safety and Potential Probiotic Traits of Lactobacillus johnsonii CNCM I-4884. Microorganisms 2022, 10, 273.

https://doi.org/10.3390/

microorganisms10020273

Academic Editors:

Mariantonietta Succi and

Elena Sorrentino

Received: 15 November 2021

Accepted: 21 January 2022

Published: 25 January 2022

Publisher's Note: MDPI stays neutral with regard to jurisdictional claims in published maps and institutional affiliations.

Copyright: (C) 2022 by the authors. Licensee MDPI, Basel, Switzerland. This article is an open access article distributed under the terms and conditions of the Creative Commons Attribution (CC BY) license (https:// creativecommons.org/licenses/by/ $4.0 /)$.

\begin{abstract}
The probiotic strain Lactobacillus johnsonii CNCM I-4884 exhibits anti-Giardia activity in vitro and in vivo in a murine model of giardiasis. The aim of this study was the identification and characterization of the probiotic potential of L. johnsonii CNCM I-4884, as well as its safety assessment. This strain was originally classified as Lactobacillus gasseri based on $16 \mathrm{~S}$ gene sequence analysis. Whole genome sequencing led to a reclassification as L. johnsonii. A genome-wide search for biosynthetic pathways revealed a high degree of auxotrophy, balanced by large transport and catabolic systems. The strain also exhibits tolerance to low $\mathrm{pH}$ and bile salts and shows strong bile salt hydrolase (BSH) activity. Sequencing results revealed the absence of antimicrobial resistance genes and other virulence factors. Phenotypic tests confirm that the strain is susceptible to a panel of 8 antibiotics of both human and animal relevance. Altogether, the in silico and in vitro results confirm that L. johnsonii CNCM I-4884 is well adapted to the gastrointestinal environment and could be safely used in probiotic formulations.
\end{abstract}

Keywords: probiotic; Lactobacillus johnsonii; genome sequencing; identification; safety

\section{Introduction}

Probiotics are defined as live microorganisms that, when administered in adequate amounts, confer a health benefit on the host [1]. Some of the better known beneficial effects of probiotics include stimulation of innate and adaptive immune response, modulation of the host metabolism (through enzymes and metabolites), anti-pathogenic activity, and stimulation of the barrier effect of the intestinal epithelium [2]. Many studies have demonstrated the beneficial effects of probiotics in a wide range of conditions, such as irritable bowel syndrome (IBS) [3], cancer [4], food allergy [5], metabolic syndrome [6], inflammatory bowel disease (IBD) [7], depression [8], Clostridioides difficile infection [9] and Giardia infection [10], among others. Importantly, the efficacy of probiotics has been shown to be strain- and disease-specific [11]. Probiotics belong mainly to microorganisms of the genera Lactobacillus, Bifidobacterium and Saccharomyces. Lactobacilli have a long history of safe use in traditional fermented foods and beverages, and some species and strains are considered important members of the healthy gut microbiota [12,13]. In addition, many members of the genus Lactobacillus are Generally Recognized As Safe (GRAS, Food and Drug Administration, USA), or included in the Qualified Presumption of Safety list (QPS, European Food Safety Authority, EU), which guarantees its use in food and safety in humans, respectively.

Lactobacillus johnsonii is a commensal bacterial species present in the gastrointestinal tract (GIT) of many mammals including mice [14], dogs [15], calves [16], yaks [17], pigs [18] 
and humans [19] associated with gut health. Some strains of L. johnsonii have been isolated from traditional fermented products $[20,21]$. Interestingly, a recommendation of the EFSA panel on Biological Hazards (BIOHAZ) has included L. johnsonii in the updated QPS list [22]. L. johnsonii has a GRAS status and is therefore considered safe; moreover, several $L$. johnsonii strains have been successfully administered as a probiotic treatment in mice $[23,24]$, rats [25], pigs [26,27], dogs [28] and humans [29,30]. Finally, L. johnsonii CNCM I-4884 has been identified as a new probiotic candidate with in vitro and in vivo anti-parasitic activity in a murine model of giardiasis [31].

EFSA has developed guidelines for the safety assessment of probiotics, which include a taxonomic identification of the strain by whole genome sequencing, genomic and phenotypic determination of the antibiotic resistance profile and safety assessment [32]. Furthermore, the host-associated stress resistance and epithelium-binding capacity of the strain should be assessed to ensure that the candidate probiotic can withstand the stressful conditions of the host GIT and transiently colonize the host to exert its functional properties [33].

The aim of this study is to investigate the safety profile and probiotic potential of the strain L. johnsonii CNCM I-4884, a Gram-positive bacterium registered in the National Collection of Microorganisms Cultures (CNCM, Pasteur Institute, Paris, France) as a class 1 bacterium. Whole genome sequencing was performed to determine taxonomical affiliation, and in vitro approaches were used to characterize the fermentation profile, resistance to acid and bile salts, and antibiotic susceptibility of the strain.

\section{Materials and Methods}

\subsection{Bacterial Strain}

Lactobacillus johnsonii CNCM I-4884 was isolated from a human sample [31]. The strain was stored at $-80^{\circ} \mathrm{C}$ in Man Rogosa Sharpe (MRS) broth (Difco, Le Pont de Claix, France) plus $20 \%$ glycerol until further analysis. The strain was routinely grown in MRS broth at $37^{\circ} \mathrm{C}$ under microaerobic conditions without agitation.

\subsection{Genome Sequencing}

Genomic DNA from CNCM I-4884 was purified using the Wizard Genomic DNA Purification kit (Promega, Madison, WI, USA) from $2 \mathrm{~mL}$ of overnight culture. The quality of the recovered DNA was confirmed by agarose gel electrophoresis (1\%) and both concentration and purity were assessed using a Nanodrop 1000 apparatus (Ozyme, Saint Quentin, France). Genomic DNA was then sequenced using Illumina MiSeq technology ( $\times 150 \mathrm{bp}$; Eurofins Genomics, Constance, Germany). Genome assembly was performed using SPAdes and annotated with the PATRIC RASTtk-enabled Genome Annotation Service [34,35]. The CG View (Circular Genome Viewer) server Beta was used to construct a circular graphical map of the genome.

\subsection{Phylogenetic Analyses}

The complete genome sequence of the species belonging to the Lactobacillus acidophilus group [36] were searched in the NCBI (National Center for Biotechnology Information) database and 18 genomes were selected: L. johnsonii UMNLJ21 (GenBank ID: CP021703), L. johnsonii UMNLJ22 (CP021704), L. johnsonii FI9785 (FN298497), L. johnsonii ATCC 33200 (ACGR00000000), L. johnsonii DPC 6026 (CP002464), L. johnsonii BS15 (CP016400), L. johnsonii NCC 533 (AE017198), L. johnsonii N6.2 (CP006811), L. taiwanensis DSM 21401 (AYZG01000000), L. taiwanensis CLG01 (CP059276), L. gasseri DSM 14869 (CP006803), L. gasseri ATCC 33323 (CP000413), L. paragasseri JCM 5343 (AP018549), L. acidophilus 20079 (CP020620), L. acidophilus La-14 (CP005926), L. acidophilus NCFM (CP000033) and L. acidophilus LA1 (CP017062). The phylogenetic position of CNCM I-4884 was determined using the PATRIC Phylogenetic Tree Service [37]. For protein comparison analysis, the L. johnsonii genomes were translated and compared to the proteins observed in the CNCM I-4884 genome. The comparison and 
visualization of the percentage identity of the proteins was generated with THE SEED server version 2.0 [38].

\subsection{Fermentation Profile}

The fermentation profile of CNCM I-4884 was determined using API 50 CHL strips (Biomérieux, Marcy-L'Etoile, France) according to the manufacturer instructions.

\subsection{Acid and Bile Salts Tolerance}

For acid tolerance, CNCM I-4884 suspension was adjusted to $1.0(\mathrm{OD} 600 \mathrm{~nm})$ with phosphate buffered saline (PBS) at pH 2.0 using $1 \mathrm{~N} \mathrm{HCl}$. After 30, 60, 90 and $120 \mathrm{~min}$ of incubation at $37^{\circ} \mathrm{C}$, suspensions were serially diluted in PBS and plated onto MRS agar. Viable cells were counted after $48 \mathrm{~h}$ incubation at $37^{\circ} \mathrm{C}$. For bile salts tolerance, MRS broth was supplemented with a mix of taurocholic acid, taurochenodeoxycholic acid, glycocholic acid and glycochenodeoxycholic acid (Sigma, Saint Louis, MO, USA) at $0.05 \mathrm{mg} / \mathrm{mL}$, $0.1 \mathrm{mg} / \mathrm{mL}, 0.5 \mathrm{mg} / \mathrm{mL}, 1 \mathrm{mg} / \mathrm{mL}$ and $2 \mathrm{mg} / \mathrm{mL}$ each. Bacterial growth was monitored at $37^{\circ} \mathrm{C}$ every $30 \mathrm{~min}$ for $24 \mathrm{~h}$ by OD at $600 \mathrm{~nm}$ using Infinite M200 Pro spectrophotometer (TECAN, Lyon, France). The experiments were performed in three biological replicates.

\subsection{Bile Salt Hydrolase Activity}

CNCM I-4884 was grown in Keiser's modified TYI-S-33 medium (KM) adjusted to $\mathrm{pH} 6.0$ and supplemented with $10 \%$ heat-inactivated fetal calf serum (FCS) for $8 \mathrm{~h}$ at $37^{\circ} \mathrm{C}$ under anaerobic conditions. Two $\mathrm{ml}$ of supernatant was transferred to a new glass tube and a mixture of conjugated bile acids (BA) was added at a final concentration of $5 \mu \mathrm{g} / \mathrm{mL}$ each The samples were then vortexed and kept at $37^{\circ} \mathrm{C}$. For each sample, experiments were stopped at different time points (0, 15, 30, $60 \mathrm{~min}$ and $2 \mathrm{~h}$ ) using three steps: (1) addition of $2 \mathrm{~mL}$ of acetonitrile supplemented with internal standard $(0.5 \mu \mathrm{g} / \mathrm{mL})$, (2) shaking, (3) centrifugation (3500 rpm for $20 \mathrm{~min}$ ) and (4) the upper phase was transferred to a new tube, then evaporated under nitrogen, and finally resuspended in $150 \mu \mathrm{L}$ of methanol. Direct enzymatic activities were detected in each experiment by the decrease of conjugated $\mathrm{BA}$, and the increase of unconjugated BA. BA concentrations were estimated by the area under curve (AUC) of the specific HPLC MS/MS BA analysis and reported as the mean BA in each experiment. The experiments included three biological replicates.

\subsection{Antibiotic Susceptibility}

The antibiotic susceptibility of CNCM I-4884 was tested by Biosafe (Biological Safety Solutions Ltd., Kuopio, Finland). Susceptibility to gentamicin, kanamycin, streptomycin, tetracycline, erythromycin, clindamycin, chloramphenicol, and ampicillin was tested according to ISO10932:2010 standard with VetMIC Lact-1 and VetMIC Lact-2 plates (SVA National Veterinary Institute, Uppsala, Sweden) under anaerobic conditions at $37^{\circ} \mathrm{C}$ for $48 \mathrm{~h}$. The minimum inhibitory concentrations (MIC) were compared with cut-off values reported by the EFSA for the obligate heterofermentative Lactobacillus group [32].

\section{Results}

\subsection{Genome Sequence}

A total of 15 contigs were obtained with an estimated genome length of 1,774,435 bp and an average GC content of $34.44 \%$. Our analysis did not reveal the presence of cryptic plasmids. Genome annotation indicated the presence of 1817 protein coding sequences (CDS), 58 transfer RNA genes and 7 ribosomal RNA genes. The annotation showed 429 hypothetical proteins and 1388 proteins with functional assignments (Figure 1A). An overview of the CNCM I-4884 genome indicates that the main subsystems of this strain are protein and DNA processing, metabolism and stress response (Figure 1B). 

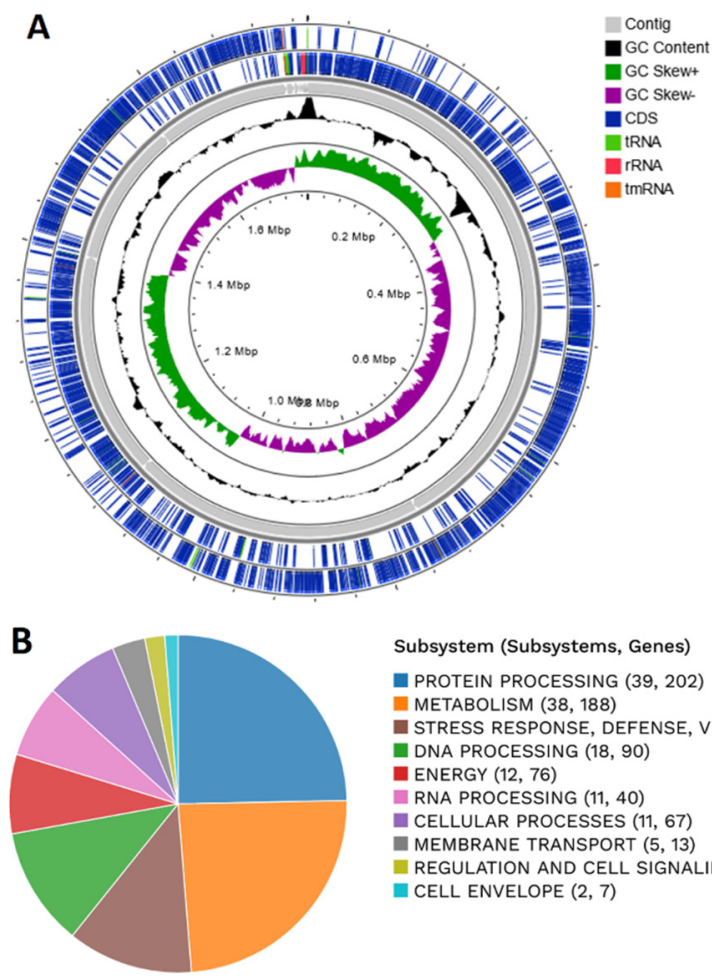

Subsystem (Subsystems, Genes)

- PROTEIN PROCESSING $(39,202)$ METABOLISM $(38,188)$

STRESS RESPONSE, DEFENSE, VIRULENCE $(19,51)$

DNA PROCESSING $(18,90)$

ENERGY $(12,76)$

RNA PROCESSING $(11,40)$

CELLULAR PROCESSES $(11,67)$

MEMBRANE TRANSPORT $(5,13)$

REGULATION AND CELL SIGNALING $(3,10)$

CELL ENVELOPE $(2,7)$

Figure 1. (A) Circular graphical map of L. johnsonii CNCM I-4884 genome. From outer to inner rings, CDS on the forward strand, CDS on the reverse strand, contigs, GC content and GC skew. (B) An overview of the RAST annotation and subsystems.

\subsection{Phylogenetic Position}

New data obtained through the investigation of the Average Nucleotide Identity (ANI) of the whole genome sequence of CNCM I-4884 and L. johnsonii NCC 533 and L. gasseri ATCC 33323 as reference organisms using OrthoANI [39], suggest that this strain belongs to the species L. johnsonii and not L. gasseri as initially identified based on the 16S gene sequence. Indeed, according to the ANI calculation, the genome of CNCM I-4884 shares $96.79 \%$ and $85.48 \%$ of the sequence with the genomes of L. johnsonii NCC 533 and L. gasseri ATCC 33323 , with $57.38 \%$ and $54.44 \%$ overlapping nucleotide sequences, respectively. The cut-off point commonly used to separate bacterial species based on their genomic sequences is 94 to $96 \%$ ANI [36,40], suggesting that CNCM I-4884 should be reclassified as L. johnsonii. The phylogenetic tree based on whole genome nucleic sequence confirmed the ANI calculations, as CNCM I-4884 grouped with other L. johnsonii strains, namely BS15, DPC 6026, NCC533, N6.2, UMNLJ21, UMNLJ22, FI9785 and ATCC 332000 (Figure 2).

To go deeper in the molecular identification of CNCM I-4884 at the strain level, the nucleic sequences of 14 phylogenetic markers of CNCM I-4884 were compared with those of available complete genomes of $L$. johnsonii strains using BLASTn (Table 1 ). The results indicate that the phylogenetic markers of CNCM I-4884 share strong nucleic sequence similarity with those of L. johnsonii ATCC 33200 (sequence identity > 99\% for all 14 phylogenetic markers tested). 


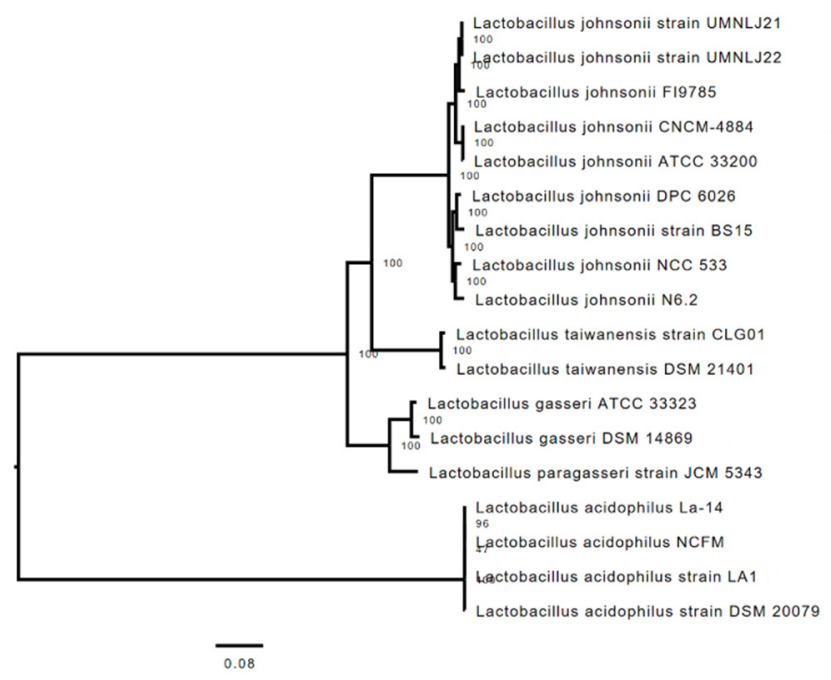

Figure 2. Phylogenetic relationship among selected lactobacilli genomes and strain CNCM I-4884.

Table 1. Percentage of nucleic sequence identity for phylogenetic markers of CNCM I-4884 compared to homologous markers in L. johnsonii and L. gasseri strains.

\begin{tabular}{|c|c|c|c|c|c|c|c|c|c|}
\hline Gene & $\begin{array}{l}\text { L. johnsonii } \\
\text { NCC } 533\end{array}$ & $\begin{array}{l}\text { L. johnsonii } \\
\text { DPC } 6026\end{array}$ & $\begin{array}{l}\text { L. johnsonii } \\
\text { UMNLJ22 }\end{array}$ & $\begin{array}{l}\text { L. johnsonii } \\
\text { UMNLJ21 }\end{array}$ & $\begin{array}{c}\text { L. johnsonii } \\
\text { BS15 }\end{array}$ & $\begin{array}{l}\text { L. johnsonii } \\
\text { ATCC } 33200\end{array}$ & $\begin{array}{c}\text { L. johnsonii } \\
\text { N6.2 }\end{array}$ & $\begin{array}{l}\text { L. johnsonii } \\
\text { FI9785 }\end{array}$ & $\begin{array}{c}\text { L. gasseri } \\
\text { ATCC } 33323\end{array}$ \\
\hline$E f-t u$ & $99.66 \%$ & $99.92 \%$ & $99.92 \%$ & $99.92 \%$ & $99.92 \%$ & $100.00 \%$ & $99.92 \%$ & $100.00 \%$ & $98.11 \%$ \\
\hline fusA & $99.28 \%$ & $99.19 \%$ & $99.71 \%$ & $99.71 \%$ & $99.20 \%$ & $100.00 \%$ & $99.24 \%$ & $99.71 \%$ & $95.57 \%$ \\
\hline gpmA & $99.57 \%$ & $99.13 \%$ & $99.42 \%$ & $99.42 \%$ & $99.58 \%$ & $100.00 \%$ & $99.57 \%$ & $99.42 \%$ & $96.83 \%$ \\
\hline gyrA & $97.51 \%$ & $97.43 \%$ & $99.40 \%$ & $99.40 \%$ & $97.39 \%$ & $100.00 \%$ & $96.02 \%$ & $99.28 \%$ & $88.48 \%$ \\
\hline gyrB & $96.95 \%$ & $96.90 \%$ & $99.44 \%$ & $99.44 \%$ & $96.95 \%$ & $100.00 \%$ & $96.90 \%$ & $99.39 \%$ & $90.30 \%$ \\
\hline iles & $97.97 \%$ & $97.20 \%$ & $99.64 \%$ & $99.64 \%$ & $97.12 \%$ & $100.00 \%$ & $97.20 \%$ & $97.77 \%$ & $86.33 \%$ \\
\hline lep $A$ & $99.45 \%$ & $99.41 \%$ & $99.03 \%$ & $99.03 \%$ & $98.12 \%$ & $100.00 \%$ & $99.45 \%$ & $99.25 \%$ & $94.99 \%$ \\
\hline leus & $98.72 \%$ & $98.82 \%$ & $99.59 \%$ & $99.59 \%$ & $98.78 \%$ & $100.00 \%$ & $98.79 \%$ & $99.65 \%$ & $89.03 \%$ \\
\hline pyrG & $98.83 \%$ & $96.86 \%$ & $99.69 \%$ & $99.69 \%$ & $96.86 \%$ & $100.00 \%$ & $98.58 \%$ & $99.63 \%$ & $89.91 \%$ \\
\hline recA & $99.44 \%$ & $99.10 \%$ & $99.54 \%$ & $99.54 \%$ & $98.98 \%$ & $100.00 \%$ & $98.98 \%$ & $99.36 \%$ & $87.22 \%$ \\
\hline recG & $96.76 \%$ & $97.06 \%$ & $96.57 \%$ & $96.57 \%$ & $97.01 \%$ & $100.00 \%$ & $96.18 \%$ & $97.06 \%$ & $85.01 \%$ \\
\hline rplB & $99.76 \%$ & $99.62 \%$ & $99.64 \%$ & $99.64 \%$ & $99.64 \%$ & $100.00 \%$ & $99.76 \%$ & $99.64 \%$ & $97.37 \%$ \\
\hline rpoB & $99.06 \%$ & $99.18 \%$ & $99.75 \%$ & $99.75 \%$ & $98.39 \%$ & $99.97 \%$ & $99.06 \%$ & $99.67 \%$ & $93.90 \%$ \\
\hline$r p s C$ & $99.40 \%$ & $99.40 \%$ & $99.70 \%$ & $99.70 \%$ & $99.40 \%$ & $100.00 \%$ & $99.40 \%$ & $99.55 \%$ & $97.76 \%$ \\
\hline
\end{tabular}

The genomes of L. johnsonii were translated and compared with the proteins observed in the genome of strain CNCM I-4884. The comparison and visualization of the percent protein identity was generated with the SEED server version 2.0 [38]. The results confirmed that the closest strain to CNCM I-4884 is L. johnsonii ATCC 33200 (Figure 3).

Altogether, these results confirm that CNCM I-4884 was incorrectly classified as L. gasseri and instead belongs to L. johnsonii species complex. The closest strain to L. johnsonii CNCM I-4884 is L. johnsonii ATCC 33200. According to the ANI calculation, the genome of CNCM I-4884 shares $99.98 \%$ of sequence identity with the genome of $L$. johnsonii ATCC 33200 , with $78.06 \%$ of nucleotide sequences overlapping.

\subsection{Biosynthetic Capacities}

No biosynthetic pathway was identified in the genome of CNCM I-4884 for most amino acids, including tryptophan, proline, methionine, histidine, valine, leucine, threonine, isoleucine, tyrosine and phenylalanine. Incomplete biosynthetic pathways were detected for serine, glycine, cysteine and lysine. However, CNCM I-4884 can synthesize aspartate from fumarate via aspartate ammonia-lyase (aspA) and alanine from cysteine via cysteine desulfurase $(i s c S)$. The presence of glutamine synthetase $(g \ln A)$ and serine hydroxymethyltransferase $(g l y A)$ indicates that CNCM I-4884 is able to interconvert glutamine and glutamate, and serine and glycine, respectively. CNCM I-4884 could assimilate ammonia by converting L-glutamine to L-glutamate through glutamine synthetase $(g \ln A)$ or by synthesizing L-asparagine from L-aspartate through asparagine synthetase $(\operatorname{asn} A)$. CNCM I-4884 is auxotrophic for purine and pyrimidine nucleotides. CNCM I-4884 lacks homologs for the enzymes necessary to synthesize many cofactors such as folate, thiamin, riboflavin, biotin, cobalamin, pantothenate, nicotinate, nicotinamide, cofactor $\mathrm{A}$ and pyridoxine. 


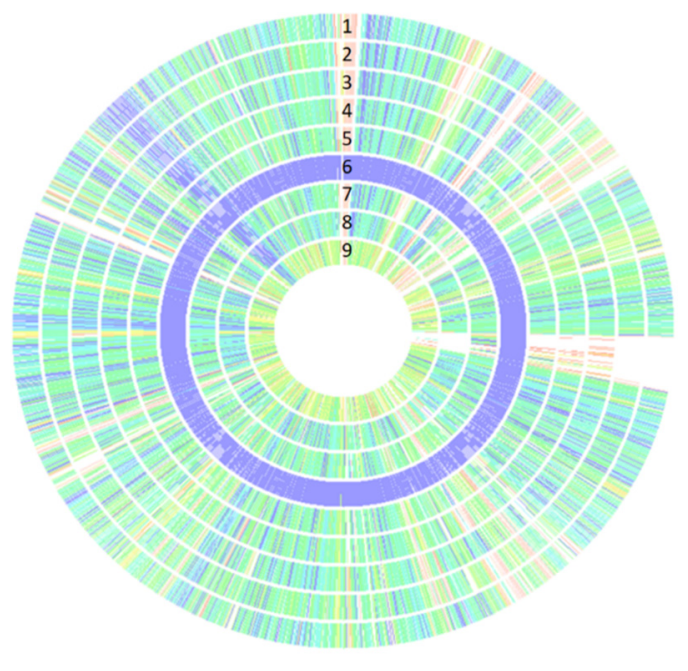

Percent protein sequence identity

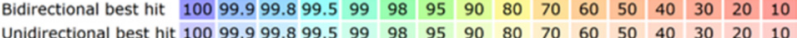

Figure 3. Comparison of protein identity in \% of L. johnsonii and L. gasseri strains using CNCM I-4884 as reference. 1, L. johnsonii UMNLJ22; 2, L. johnsonii N6.2; 3, L. johnsonii FI9785; 4, L. johnsonii DPC 6026; 5, L. johnsonii BS15; 6, L. johnsonii ATCC 33200; 7, L. johnsonii NCC 533, 8, L. johnsonii UMNLJ21; 9, L. gasseri ATCC 33323. The red bar represents $10 \%$ identity and the blue bar represents $100 \%$.

The genome of CNCM I-4884 encodes 15 ATP binding cassette (ABC)-type transporters, which translocate both amino acids and oligopeptides. An ABC-type transporter was identified for spermidine and putrescine (pot $A-D)$. The CNCM I-4884 genome encodes 25 putative PTS systems (PTS) with predicted specificities for fructose, lactose, galactose, sorbose, maltose, sucrose, trehalose, mannose, tagatose, cellobiose and $\mathrm{N}$-acetylglucosamine. This large number of predicted transporters was complemented by an array of 15 peptidases and proteases. To confirm the carbohydrate metabolism predictions, Analytical Profile Index (API) identification was performed using rapid API-50 $\mathrm{CH}$ biochemical test kit. Biochemical activity was positive for D-galactose, D-glucose, D-fructose, D-mannose, N-Acetylglucosamine, arbutine, esculine, salicine, D-cellobiose, D-maltose, D-lactose, D-saccharose, D-raffinose, amidon, gentibiose and D-tagatose (Table 2).

\subsection{Stress Resistance}

The genome of CNCM I-4884 was searched for stress-related genes. CNCM I-4884 genome encodes genes involved in cell envelope modifications, such as the eps gene cluster (eps A-E, epsIJ, and epsUV), the dlt operon and $c f a 2$, which have been associated with improved survival under gut conditions [41-45]. CNCM I-4884 is also well equipped for DNA and protein protection in response to stress. DNA repair and protection genes were identified: the transcriptional regulators $\operatorname{lex} A$ and $\operatorname{rec} A$, SOS regulon $\operatorname{rec} A D F J N O R, r u v A B$, and ssb, the exonuclease ATP-binding cassette complex $u v r A B C D, m f d$ and $x t h$, the homology-independent facilitator complex gyr $A B$ and top $A$, and low-fidelity DNA polymerases $\operatorname{din} B$ and $d n a E$ [46]. In order to maintain the protein integrity under stress conditions, CNCM I-4884 encodes a large collection of chaperone-active proteins such as GroES, GroEL, GrpE, HtpG, Hsp33, Hsp20, DnaK, DnaJ, HtrA, FtsH, EF-Tu, EF-G and the proteolytic Pta-AckA pathway, especially pivotal for long-term acid and bile stress resistance [46-50]. CNCM I-4884 also encodes the well-conserved heat shock proteins ClpA, ClpC, ClpE, ClpP, ClpX, HslU and Hslv, particularly important for the rapid response of lactobacilli when encountering adverse conditions in the gut [51-54]. CNCM I-4884 is able to cope with oxidative stress with two thioredoxin genes $(\operatorname{tr} x A$ and $\operatorname{tr} x H)$, thioredoxin reductase $(\operatorname{tr} x B)$, glutathione reductase $(g s h R 1)$, and two methionine sulfoxide reductase ( $m s r A$ and $m r s B$ ) [55-57]. CNCM I-4884 encodes efflux systems for active clearance of acid- and bile-related stress factors including the MFS transporter $(m d r T)$, 
ABC transporters (opuA, opp $A, c c m A, m d l A$ and $m d l B)$ and $\mathrm{Na}^{+} / \mathrm{H}^{+}$antiporters (nap $A$, nhaP and $\operatorname{trk} A)[41,51,52,58-60]$.

Table 2. Carbohydrate fermentation profile of CNCM I-4884 assessed by API 50 CH test strips.

\begin{tabular}{|c|c|c|c|}
\hline Substrate & Result & Substrate & Result \\
\hline Glycerol & - & Esculine & + \\
\hline Erythritol & - & Salicine & + \\
\hline D-arabinose & - & D-cellobiose & + \\
\hline L-arabinose & - & D-maltose & + \\
\hline D-ribose & - & D-lactose & + \\
\hline D-xylose & - & D-melibiose & - \\
\hline L-xylose & - & D-saccharose & + \\
\hline D-Adonitol & - & D-threalose & - \\
\hline $\begin{array}{c}\text { Methyl- } \beta \text { D- } \\
\text { xylopyranoside }\end{array}$ & - & Inulin & - \\
\hline D-galactose & + & D-melezitose & - \\
\hline D-glucose & + & D-raffinose & + \\
\hline D-fructose & + & Starch & + \\
\hline D-mannose & + & Glycogene & - \\
\hline L-sorbose & - & Xylitol & - \\
\hline L-rhamnose & - & Gentiobiose & + \\
\hline Dulcitol & - & D-turanose & - \\
\hline Inositol & - & D-lyxose & - \\
\hline D-mannitol & - & D-tagatose & + \\
\hline D-sorbitol & - & D-fucose & - \\
\hline $\begin{array}{c}\text { Methyl- } \alpha \mathrm{D} \text { - } \\
\text { mannopyranoside }\end{array}$ & - & D-arabitol & - \\
\hline $\begin{array}{l}\text { Methyl- } \alpha \mathrm{D}- \\
\text { glucopyranoside }\end{array}$ & - & Potassium gluconate & - \\
\hline $\mathrm{N}$-acetylglucosamine & + & $\begin{array}{c}\text { Potassium } \\
\text { 2-cetogluconate }\end{array}$ & - \\
\hline Amygdaline & - & $\begin{array}{c}\text { Potassium } \\
\text { 5-cetogluconate }\end{array}$ & - \\
\hline Arbutine & + & & \\
\hline
\end{tabular}

The acid tolerance of CNCM I-4884 was tested at pH 2.0 (Figure 4A). CNCM I-4884 showed good acid tolerance, with more than $50 \%$ viability after $60 \mathrm{mn}$ of exposure. When grown in the presence of bile salts, CNCM I-4884 is able to grow in the presence of 0.05 to $0.5 \mathrm{mg} / \mathrm{mL}$ bile salts (Figure $4 \mathrm{~B}$ ). These results suggest that the strain may not require protective encapsulation to successfully pass through the host GIT.
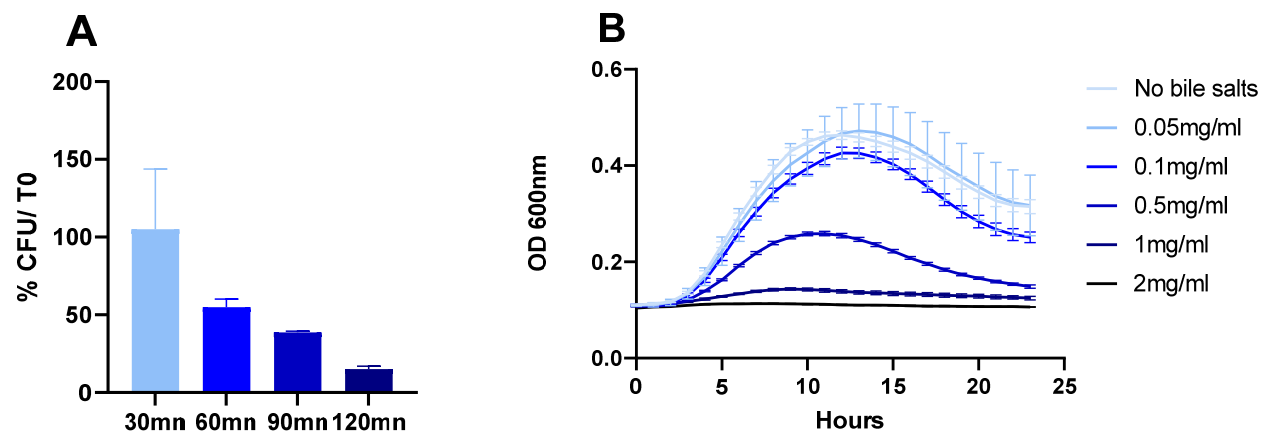

Figure 4. CNCM I-4884 tolerance to (A) $\mathrm{pH} 2.0$ and to (B) conjugated bile salts.

Furthermore, the good tolerance of CNCM I-4884 to bile salts is explained by the presence of three genes encoding bile salt hydrolases (BSH), involved in bile detoxification. The BSH activity of CNCM I-4884 was assessed for a panel of tauro- and glyco-conjugated 
bile salts (Figure 5). The results indicate BSH activity towards both tauro- and glycoconjugated substrates, with a maximum activity for taurochenodeoxycholic acid (TCDCA), taurodeoxycholic acid (TDCA) and taurocholic acid (TCA).
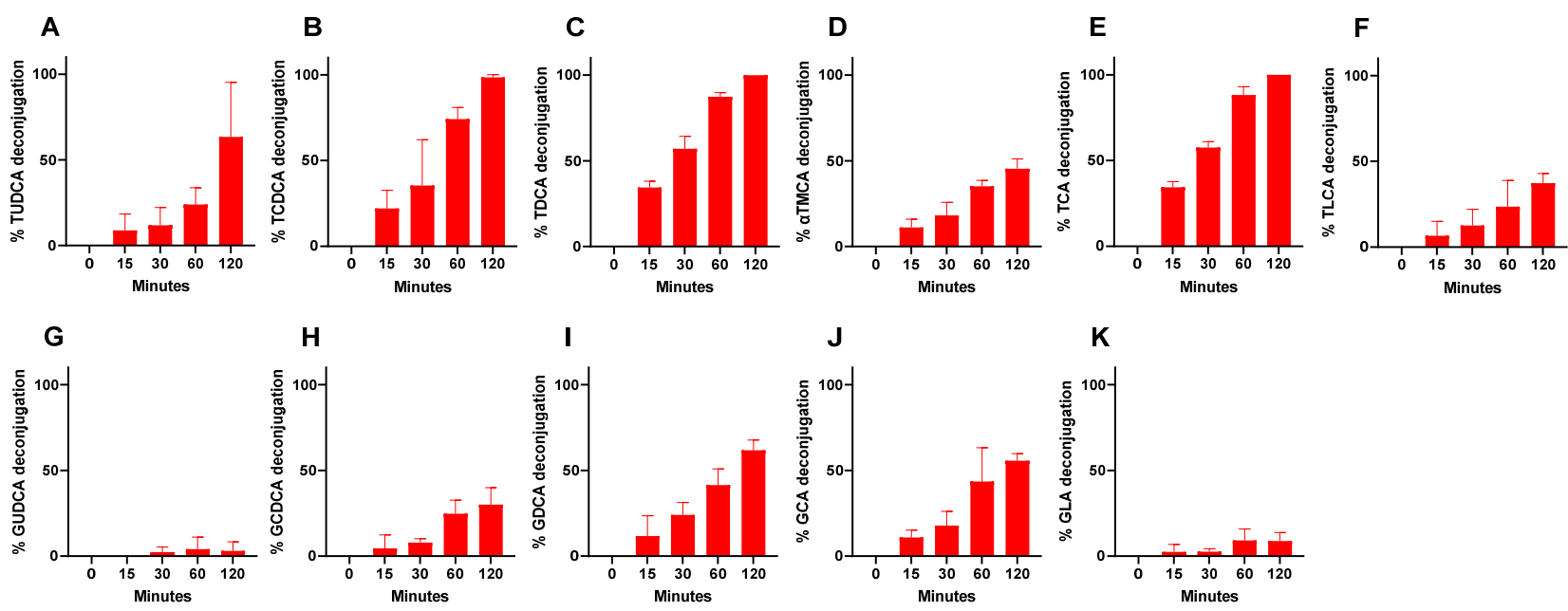

Figure 5. Bile acids deconjugation activity of CNCM I-4884 supernatant (A-K) TUDCA, tauroursodeoxycholic acid; TCDCA, taurochenodeoxycholic acid; TDCA, taurodeoxycholic acid; TCA, taurocholic acid; TLCA, taurolitocholic acid; $\alpha$ TMCA, $\alpha$-tauromuricholic acid; GUDCA, glycoursodeoxycholic acid; GCDCA, glycochenodeoxycholic acid; GDCA, glycodeoxycholic acid; GCA, glycocholic acid; GLC, glycolitocholic acid. Values are expressed as percentage \pm SEM (standard error of the mean). Data are the means of three independent replicates.

\subsection{In Silico Search for Adhesion Factors}

In general, it is assumed that a good ability to adhere to the intestinal epithelium or the mucus layer is a desirable trait for probiotic bacteria, as this may increase the residence time in the GIT and facilitate interactions with host cells. Among the different factors involved in epithelial adhesion, exopolysaccharides (EPS) often play a role in the nonspecific interactions of lactobacilli with epithelial cells. EPS may serve as a protective layer against harsh conditions during GIT transit. Once the bacteria reach the colon, EPS are involved in the interaction with the intestinal mucosa, with both positive and negative effects on the adhesion (depending on the literature) [61,62]. In general, the presence of EPS could reduce adhesion to intestinal cells, due to shielding of surface macromolecules acting as adhesins, or electrostatically interfere with the binding to receptors of mucosal surface. However, EPS could also act as ligands, mediating specific adhesion and co-aggregation. CNCM I-4884 possess nine genes of the EPS cluster (epsA-epsE, epsI, epsJ, epsU and epsV) but lacks homologs of EpsF. Another factor involved in adhesion to intestinal epithelial cells is lipoteichoic acid (LTA). LTAs are major components of the cell-wall of most Gram-positive bacteria and are often replaced by glycosyl or D-alanyl (D-Ala) esters by the action of four gene products (DltA to DltD). The four genes of the dlt operon were identified in the genome of CNCM I-4884. D-alanylation has been shown to result in enhanced adhesion to intestinal epithelial cells and colonization of the GIT in vivo [63].

The presence of four genes (apf1, apf2, gtfA and inu) encoding aggregation promoting factors (APF) in the genome of CNCM I-4884 is likely responsible for the strong aggregation phenotype of the strain (data not shown). APFs have been shown to contribute to survival during passage through the GIT by influencing stress tolerance and interacting with the host intestinal mucosa, as well as fibronectin, mucin and laminin, contributing to colonization [64-68]. In addition, the genome of CNCM I-4884 contains other genes involved in adhesion to extracellular matrix components such as fibronectin binding proteins $(f b p A$, enoA1 and enoA2) and mucus-binding proteins ( $m u b, m s a, m a p A, s r t A)$ [69-72]. 


\subsection{Antibiotic Resistance}

The RGI program was used to comprehensively scan the genome of CNCM I-4884 against the CARD database of antibiotic resistance genes, as well as mutations in antibiotics targets known to confer resistance [73]. No known resistance genes were found. The susceptibility of CNCM I-4884 to a panel of eight antibiotics was determined by the Minimum Inhibitory Concentration (MIC) assay and compared with the most recent EFSA breakpoint values (Table 3). The MIC obtained for gentamycin, kanamycin, streptomycin, erythromycin, clindamycin, chloramphenicol and ampicillin are below the cut-off values. Although the MIC of tetracycline exceeds the cut-off concentration, this is within the inter-laboratory variation of MICs reported for non-enterococcal lactic acid bacteria [74]. Therefore, it was concluded that CNCM I-4884 was sensitive to all antibiotics of human and animal relevance requested by EFSA.

Table 3. Minimum Inhibitory Concentrations (MIC) of antibiotic required by EFSA for CNCM I-4884.

\begin{tabular}{ccc}
\hline Antibiotic & MIC $\mu \mathrm{g} / \mathbf{m L}$ & EFSA MIC Cut-Off $\boldsymbol{\mu g} / \mathbf{m L}$ \\
\hline Gentamycin & $\leq 0.5$ & 16 \\
Kanamycin & 8 & 64 \\
Streptomycin & 8 & 64 \\
Tetracycline & 16 & 8 \\
Erythromycin & 0.5 & 1 \\
Clindamycin & 0.12 & 4 \\
Chloramphenicol & 4 & 4 \\
Ampicillin & 1 & 2 \\
\hline
\end{tabular}

\subsection{Virulence Factors}

The VF Analyser pipeline from the Virulence Factor Database [75] and VirulenceFinder 2.0.3 of the Center for Genomic Epidemiology [76] were used to search for offensive virulence factors of major bacterial pathogen species of medical importance in the genome of CNCM I-4884. The search results in these two databases were negative. Therefore, CNCM I- 4884 could be considered free of virulence factors and safe for probiotic applications.

\section{Discussion and Conclusions}

L. johnsonii CNCM I-4884 was selected from a previous screening based on anti-Giardia activity in vitro and in vivo in a murine model of giardiasis. This strain significantly antagonizes parasite growth with a drastic reduction in small intestinal trophozoite load and cyst excretion. The protective effect of CNCM I-4884 was higher to that of the reference strain L. johnsonii La1 [31]. The aim of this study was the identification of CNCM -4884 based on the whole genome sequence, as well as the assessment of its safety and probiotic properties.

To be considered suitable for use as a probiotic, a candidate bacterial strain must be unequivocally identified. The $16 \mathrm{~S}$ gene sequence of strain CNCM I-4884 shares strong similarity with L. gasseri species, so CNCM I-4884 was originally classified as L. gasseri. To confirm the identity of CNCM I-4884, whole genome sequencing was performed using Illumina technology. The new results led to the reclassification of CNCM I-4884 as L. johnsonii, a species closely related to L. gasseri (which shares the same phylogenetic species complex) [36,77]. The closest strain to CNCM I-4884 is currently L. johnsonii ATCC 33200.

CNCM I-4884 is a strain that appears unable to synthesize de novo most amino acids and vitamins. Thus, this strain is dependent on large amounts of exogenous amino acids and peptides to supply protein synthesis and is therefore restricted to environments rich in such substrates. This high degree of auxotrophy is found in most lactobacilli, especially among species of the L. acidophilus group and reflects their demanding nutritional requirements when grown on synthetic media [13,78,79]. CNCM I-4884 counterbalances its limited biosynthetic capacities by relying on enhanced transport systems to acquire cofactors, amino acids, and other essential precursors exogenously. Its complex proteolytic system also likely provides CNCM I-4884 with a selective advantage, as acquisition of amino 
acids from the environment is energetically more favorable than de novo synthesis. CNCM I-4884 possess diverse carbohydrate transport systems and catabolic potential, which have previously been suggested to promote the ability to compete in environmental niches where sugar molecules may be abundant, such as the upper GIT of mammalian hosts [80,81].

The ability to survive the harsh conditions of the GIT is one of the vital characteristics that allows a probiotic bacterial strain to transiently colonize the host. Genome analysis of CNCM I-4884 predicts that the strain is well equipped to deal with different environmental stresses, such as acid, bile and oxidative stresses. In vitro tests revealed that CNCM I-4884 showed a good tolerance to $\mathrm{pH} 2.0$ and to conjugated bile salts. In vitro BSH activity results showed good hydrolytic activity against both tauro- and glyco-conjugated BA. BA are synthesized from cholesterol and are subsequently conjugated with either taurine or glycine in the liver and finally released into the duodenum. Upon reaching the colon, BSH enzymes of the commensal microbiota modify bile salts by hydrolyzing the amide bond between amino acids and cholesterol. The role of BSHs in bile detoxification has been well demonstrated. High concentrations of bile could dissolve phospholipids and alter the structure of the lipid bilayer of membranes, causing their lysis. In addition, BA induce protein misfolding, oxidative damage to DNA and RNA, and intracellular acidification. BSH-producing bacteria can be protected by the formation of weaker unconjugated counterparts with lower solubility and emulsification capacity [82]. In addition, the liberated glycine and taurine could be used as carbon, nitrogen, and energy sources, conferring a nutritional advantage on hydrolytic bacterial strains [83]. BSH enzymes are almost exclusively associated with mammals gut-colonizing bacteria and confer a clear selective advantage in the GIT environment [84,85].

Furthermore, to exert a better beneficial effect, a probiotic strain must adhere to the intestinal mucosa or upper mucus layer. A genome-wide search of CNCM I-4884 for adhesion factors revealed the presence of a significant number of genes involved in autoaggregation, adhesion to intestinal epithelial cells and binding to several components of the extracellular matrix, such as fibronectin, laminin and mucin. Altogether, these results suggest that CNCM I-4884 could persist in vivo by transiently colonizing the mucus layer and/or the intestinal epithelium.

The ability of a probiotic strain to transfer antibiotic resistance elements to opportunistic or pathogenic organisms through horizontal gene transfer is of paramount concern. Phenotypic testing based on MIC determination revealed that CNCM I-4884 is sensitive to most antibiotics relevant for use in humans and animals (according to the EFSA guidelines). A whole genome sequence search for the presence of known antimicrobial resistance genes confirmed the absence of acquired or transferable resistance factors and plasmids.

In conclusion, the results obtained in silico and in vitro demonstrate that L. johnsonii CNCM I-4884 represents a safe candidate for probiotic applications.

Author Contributions: Conceptualization, L.G.B.-H., I.F. and B.P.; methodology, A.-S.B., L.G.B.H., I.F. and B.P.; software, A.-S.B.; validation, L.G.B.-H., I.F. and B.P.; formal analysis, A.-S.B. and L.G.B.-H.; investigation, A.-S.B.; resources, L.G.B.-H. and P.L.; data curation, A.-S.B. and L.G.B.-H.; writing-original draft preparation, A.-S.B. and L.G.B.-H.; writing-review and editing, A.-S.B., B.P., I.F., P.L. and L.G.B.-H.; supervision, L.G.B.-H.; project administration, L.G.B.-H. and P.L.; funding acquisition, L.G.B.-H. All authors have read and agreed to the published version of the manuscript.

Funding: This research was funded by Boehringer Ingelheim and Association Nationale de la Recherche et de la Technologie (2019/0369).

Institutional Review Board Statement: Not applicable.

Informed Consent Statement: Not applicable.

Data Availability Statement: The whole genome sequence has been deposited at GenBank under the accession JAIQXC000000000.

Acknowledgments: We thank Emilie Gauliard and Dominique Rainteau for LC-MS/MS analyses. 
Conflicts of Interest: The authors declare that A.S.B. received a salary from Boehringer Ingelheim, as part of a CIFRE contract. The other authors declare no competing interests.

\section{References}

1. Hill, C.; Guarner, F.; Reid, G.; Gibson, G.R.; Merenstein, D.J.; Pot, B.; Morelli, L.; Canani, R.B.; Flint, H.J.; Salminen, S.; et al. The International Scientific Association for Probiotics and Prebiotics Consensus Statement on the Scope and Appropriate Use of the Term Probiotic. Nat. Rev. Gastroenterol. Hepatol. 2014, 11, 506-514. [CrossRef] [PubMed]

2. Sanders, M.E.; Merenstein, D.J.; Reid, G.; Gibson, G.R.; Rastall, R.A. Probiotics and Prebiotics in Intestinal Health and Disease: From Biology to the Clinic. Nat. Rev. Gastroenterol. Hepatol. 2019, 16, 605-616. [CrossRef] [PubMed]

3. Ishaque, S.M.; Khosruzzaman, S.M.; Ahmed, D.S.; Sah, M.P. A Randomized Placebo-Controlled Clinical Trial of a Multi-Strain Probiotic Formulation (Bio-Kult ${ }^{\circledR}$ ) in the Management of Diarrhea-Predominant Irritable Bowel Syndrome. BMC Gastroenterol. 2018, 18, 71. [CrossRef] [PubMed]

4. Zaharuddin, L.; Mokhtar, N.M.; Muhammad Nawawi, K.N.; Raja Ali, R.A. A Randomized Double-Blind Placebo-Controlled Trial of Probiotics in Post-Surgical Colorectal Cancer. BMC Gastroenterol. 2019, 19, 131. [CrossRef] [PubMed]

5. Nocerino, R.; Di Costanzo, M.; Bedogni, G.; Cosenza, L.; Maddalena, Y.; Di Scala, C.; Della Gatta, G.; Carucci, L.; Voto, L.; Coppola, S.; et al. Dietary Treatment with Extensively Hydrolyzed Casein Formula Containing the Probiotic Lactobacillus rhamnosus GG Prevents the Occurrence of Functional Gastrointestinal Disorders in Children with Cow's Milk Allergy. J. Pediatr. 2019, 213, 137-142.e2. [CrossRef]

6. Kassaian, N.; Feizi, A.; Aminorroaya, A.; Amini, M. Probiotic and Synbiotic Supplementation Could Improve Metabolic Syndrome in Prediabetic Adults: A Randomized Controlled Trial. Diabetes Metab. Syndr. Clin. Res. Rev. 2019, 13, 2991-2996. [CrossRef]

7. Bjarnason, I.; Sission, G.; Hayee, B. A Randomised, Double-Blind, Placebo-Controlled Trial of a Multi-Strain Probiotic in Patients with Asymptomatic Ulcerative Colitis and Crohn's Disease. Inflammopharmacology 2019, 27, 465-473. [CrossRef]

8. Akkasheh, G.; Kashani-Poor, Z.; Tajabadi-Ebrahimi, M.; Jafari, P.; Akbari, H.; Taghizadeh, M.; Memarzadeh, M.R.; Asemi, Z.; Esmaillzadeh, A. Clinical and Metabolic Response to Probiotic Administration in Patients with Major Depressive Disorder: A Randomized, Double-Blind, Placebo-Controlled Trial. Nutrition 2016, 32, 315-320. [CrossRef]

9. Barker, A.K.; Duster, M.; Valentine, S.; Hess, T.; Archbald-Pannone, L.; Guerrant, R.; Safdar, N. A Randomized Controlled Trial of Probiotics for Clostridium difficile Infection in Adults (PICO). J. Antimicrob. Chemother. 2017, 72, 3177-3180. [CrossRef]

10. Travers, M.-A.; Florent, I.; Kohl, L.; Grellier, P. Probiotics for the Control of Parasites: An Overview. J. Parasitol. Res. 2011, 2011, 610769. [CrossRef]

11. McFarland, L.V.; Evans, C.T.; Goldstein, E.J.C. Strain-Specificity and Disease-Specificity of Probiotic Efficacy: A Systematic Review and Meta-Analysis. Front. Med. 2018, 5, 124. [CrossRef] [PubMed]

12. Gasbarrini, G.; Bonvicini, F.; Gramenzi, A. Probiotics History. J. Clin. Gastroenterol. 2016, 50, S116-S119. [CrossRef] [PubMed]

13. Duar, R.M.; Lin, X.B.; Zheng, J.; Martino, M.E.; Grenier, T.; Pérez-Muñoz, M.E.; Leulier, F.; Gänzle, M.; Walter, J. Lifestyles in Transition: Evolution and Natural History of the Genus Lactobacillus. FEMS Microbiol. Rev. 2017, 41, S27-S48. [CrossRef] [PubMed]

14. Kim, D.; Cho, M.; Cho, S.; Lee, Y.; Byun, S.J.; Lee, S. Complete Genome Sequence of Lactobacillus johnsonii Strain Byun-Jo-01, Isolated from the Murine Gastrointestinal Tract. Microbiol. Resour. Announc. 2018, 7, e00985-18. [CrossRef]

15. Masuoka, H.; Shimada, K.; Kiyosue-Yasuda, T.; Kiyosue, M.; Oishi, Y.; Kimura, S.; Yamada, A.; Hirayama, K. Transition of the Intestinal Microbiota of Dogs with Age. Biosci. Microbiota Food Health 2017, 36, 27-31. [CrossRef]

16. Fernández, S.; Fraga, M.; Silveyra, E.; Trombert, A.N.; Rabaza, A.; Pla, M.; Zunino, P. Probiotic Properties of Native Lactobacillus Spp. Strains for Dairy Calves. Benef. Microbes 2018, 9, 613-624. [CrossRef]

17. Wang, Y.; Li, A.; Jiang, X.; Zhang, H.; Mehmood, K.; Zhang, L.; Jiang, J.; Waqas, M.; Iqbal, M.; Li, J. Probiotic Potential of Leuconostoc pseudomesenteroides and Lactobacillus Strains Isolated From Yaks. Front. Microbiol. 2018, 9, 2987. [CrossRef]

18. Zhang, W.; Wang, J.; Zhang, D.; Liu, H.; Wang, S.; Wang, Y.; Ji, H. Complete Genome Sequencing and Comparative Genome Characterization of Lactobacillus johnsonii ZLJ010, a Potential Probiotic With Health-Promoting Properties. Front. Genet. 2019, 10, 812. [CrossRef]

19. Zhang, X.; Mushajiang, S.; Luo, B.; Tian, F.; Ni, Y.; Yan, W. The Composition and Concordance of Lactobacillus Populations of Infant Gut and the Corresponding Breast-Milk and Maternal Gut. Front. Microbiol. 2020, 11, 597911. [CrossRef]

20. Zielińska, D.; Rzepkowska, A.; Radawska, A.; Zieliński, K. In Vitro Screening of Selected Probiotic Properties of Lactobacillus Strains Isolated from Traditional Fermented Cabbage and Cucumber. Curr. Microbiol. 2015, 70, 183-194. [CrossRef]

21. Vizoso Pinto, M.G.; Franz, C.M.A.P.; Schillinger, U.; Holzapfel, W.H. Lactobacillus Spp. with in Vitro Probiotic Properties from Human Faeces and Traditional Fermented Products. Int. J. Food Microbiol. 2006, 109, 205-214. [CrossRef] [PubMed]

22. EFSA Panel on Biological Hazards (BIOHAZ); Koutsoumanis, K.; Allende, A.; Álvarez-Ordóñez, A.; Bolton, D.; Bover-Cid, S.; Chemaly, M.; Davies, R.; Hilbert, F.; Lindqvist, R.; et al. Update of the List of QPS-recommended Biological Agents Intentionally Added to Food or Feed as Notified to EFSA 9: Suitability of Taxonomic Units Notified to EFSA until September 2018. EFSA J. 2019, 17, e05555. [CrossRef] [PubMed]

23. Aiba, Y.; Umeda, K.; Rahman, S.; Nguyen, S.V.; Komatsu, Y. Synergistic Effect of Anti-Helicobacter pylori Urease Immunoglobulin Y from Egg Yolk of Immunized Hens and Lactobacillus johnsonii No.1088 to Inhibit the Growth of Helicobacter pylori in Vitro and in Vivo. Vaccine 2019, 37, 3106-3112. [CrossRef] [PubMed] 
24. Bereswill, S.; Ekmekciu, I.; Escher, U.; Fiebiger, U.; Stingl, K.; Heimesaat, M.M. Lactobacillus johnsonii Ameliorates Intestinal, Extra-Intestinal and Systemic Pro-Inflammatory Immune Responses Following Murine Campylobacter jejuni Infection. Sci. Rep. 2017, 7, 2138. [CrossRef]

25. Teixeira, L.D.; Kling, D.N.; Lorca, G.L.; Gonzalez, C.F. Lactobacillus johnsonii N6.2 Diminishes Caspase-1 Maturation in the Gastrointestinal System of Diabetes Prone Rats. Benef. Microbes 2018, 9, 527-539. [CrossRef]

26. Xin, J.; Zeng, D.; Wang, H.; Sun, N.; Zhao, Y.; Dan, Y.; Pan, K.; Jing, B.; Ni, X. Probiotic Lactobacillus johnsonii BS15 Promotes Growth Performance, Intestinal Immunity, and Gut Microbiota in Piglets. Probiotics Antimicrob. Proteins 2020, 12, 184-193. [CrossRef]

27. Xia, B.; Yu, J.; He, T.; Liu, X.; Su, J.; Wang, M.; Wang, J.; Zhu, Y. Lactobacillus johnsonii L531 Ameliorates Enteritis via Elimination of Damaged Mitochondria and Suppression of SQSTM1-dependent Mitophagy in a Salmonella infantis Model of Piglet Diarrhea. FASEB J. 2020, 34, 2821-2839. [CrossRef]

28. Kumar, S.; Pattanaik, A.K.; Sharma, S.; Jadhav, S.E.; Dutta, N.; Kumar, A. Probiotic Potential of a Lactobacillus Bacterium of Canine Faecal-Origin and Its Impact on Select Gut Health Indices and Immune Response of Dogs. Probiotics Antimicrob. Proteins 2017, 9, 262-277. [CrossRef]

29. Garrido, D.; Suau, A.; Pochart, P.; Cruchet, S.; Gotteland, M. Modulation of the Fecal Microbiota by the Intake of a Lactobacillus johnsonii La1-Containing Product in Human Volunteers. FEMS Microbiol. Lett. 2005, 248, 249-256. [CrossRef]

30. Davoren, M.J.; Liu, J.; Castellanos, J.; Rodríguez-Malavé, N.I.; Schiestl, R.H. A Novel Probiotic, Lactobacillus johnsonii 456, Resists Acid and Can Persist in the Human Gut beyond the Initial Ingestion Period. Gut Microbes 2019, 10, 458-480. [CrossRef]

31. Allain, T.; Chaouch, S.; Thomas, M.; Travers, M.-A.; Valle, I.; Langella, P.; Grellier, P.; Polack, B.; Florent, I.; Bermúdez-Humarán, L.G. Bile Salt Hydrolase Activities: A Novel Target to Screen Anti-Giardia Lactobacilli? Front. Microbiol. 2018, 9, 89. [CrossRef] [PubMed]

32. EFSA Panel on Additives and Products or Substances used in Animal Feed (FEEDAP); Rychen, G.; Aquilina, G.; Azimonti, G.; Bampidis, V.; Bastos, M.dL.; Bories, G.; Chesson, A.; Cocconcelli, P.S.; Flachowsky, G.; et al. Guidance on the Characterisation of Microorganisms Used as Feed Additives or as Production Organisms. EFSA J. 2018, 16, e05206. [CrossRef] [PubMed]

33. de Melo Pereira, G.V.; de Oliveira Coelho, B.; Magalhães Júnior, A.I.; Thomaz-Soccol, V.; Soccol, C.R. How to Select a Probiotic? A Review and Update of Methods and Criteria. Biotechnol. Adv. 2018, 36, 2060-2076. [CrossRef] [PubMed]

34. Brettin, T.; Davis, J.J.; Disz, T.; Edwards, R.A.; Gerdes, S.; Olsen, G.J.; Olson, R.; Overbeek, R.; Parrello, B.; Pusch, G.D.; et al RASTtk: A Modular and Extensible Implementation of the RAST Algorithm for Building Custom Annotation Pipelines and Annotating Batches of Genomes. Sci. Rep. 2015, 5, 8365. [CrossRef]

35. Wattam, A.R.; Davis, J.J.; Assaf, R.; Boisvert, S.; Brettin, T.; Bun, C.; Conrad, N.; Dietrich, E.M.; Disz, T.; Gabbard, J.L.; et al. Improvements to PATRIC, the All-Bacterial Bioinformatics Database and Analysis Resource Center. Nucleic Acids Res. 2017, 45, D535-D542. [CrossRef]

36. Wittouck, S.; Wuyts, S.; Meehan, C.J.; van Noort, V.; Lebeer, S. A Genome-Based Species Taxonomy of the Lactobacillus Genus Complex. mSystems 2019, 5, e0064-19. [CrossRef]

37. Davis, J.J.; Gerdes, S.; Olsen, G.J.; Olson, R.; Pusch, G.D.; Shukla, M.; Vonstein, V.; Wattam, A.R.; Yoo, H. PATtyFams: Protein Families for the Microbial Genomes in the PATRIC Database. Front. Microbiol. 2016, 7, 118. [CrossRef]

38. Overbeek, R.; Olson, R.; Pusch, G.D.; Olsen, G.J.; Davis, J.J.; Disz, T.; Edwards, R.A.; Gerdes, S.; Parrello, B.; Shukla, M.; et al The SEED and the Rapid Annotation of Microbial Genomes Using Subsystems Technology (RAST). Nucleic Acids Res. 2014, 42, D206-D214. [CrossRef]

39. Yoon, S.-H.; Ha, S.; Lim, J.; Kwon, S.; Chun, J. A Large-Scale Evaluation of Algorithms to Calculate Average Nucleotide Identity. Antonie Van Leeuwenhoek 2017, 110, 1281-1286. [CrossRef]

40. Richter, M.; Rosselló-Móra, R. Shifting the Genomic Gold Standard for the Prokaryotic Species Definition. Proc. Natl. Acad. Sci. USA 2009, 106, 19126-19131. [CrossRef]

41. Hamon, E.; Horvatovich, P.; Izquierdo, E.; Bringel, F.; Marchioni, E.; Aoudé-Werner, D.; Ennahar, S. Comparative Proteomic Analysis of Lactobacillus plantarum for the Identification of Key Proteins in Bile Tolerance. BMC Microbiol. 2011, 11, 63. [CrossRef] [PubMed]

42. Revilla-Guarinos, A.; Alcántara, C.; Rozès, N.; Voigt, B.; Zúñiga, M. Characterization of the Response to Low pH of Lactobacillus casei $\triangle$ RR12, a Mutant Strain with Low D-Alanylation Activity and Sensitivity to Low pH. J. Appl. Microbiol. 2014, 116, 1250-1261. [CrossRef] [PubMed]

43. Shabala, L.; Ross, T. Cyclopropane Fatty Acids Improve Escherichia coli Survival in Acidified Minimal Media by Reducing Membrane Permeability to H+ and Enhanced Ability to Extrude H+. Res. Microbiol. 2008, 159, 458-461. [CrossRef] [PubMed]

44. Vélez, M.P.; Verhoeven, T.L.A.; Draing, C.; Von Aulock, S.; Pfitzenmaier, M.; Geyer, A.; Lambrichts, I.; Grangette, C.; Pot, B.; Vanderleyden, J.; et al. Functional Analysis of D-Alanylation of Lipoteichoic Acid in the Probiotic Strain Lactobacillus rhamnosus GG. Appl. Environ. Microbiol. 2007, 73, 3595-3604. [CrossRef]

45. Dertli, E.; Mayer, M.J.; Narbad, A. Impact of the Exopolysaccharide Layer on Biofilms, Adhesion and Resistance to Stress in Lactobacillus johnsonii FI9785. BMC Microbiol. 2015, 15, 8. [CrossRef]

46. Papadimitriou, K.; Alegría, Á.; Bron, P.A.; de Angelis, M.; Gobbetti, M.; Kleerebezem, M.; Lemos, J.A.; Linares, D.M.; Ross, P.; Stanton, C.; et al. Stress Physiology of Lactic Acid Bacteria. Microbiol. Mol. Biol. Rev. 2016, 80, 837-890. [CrossRef]

47. Bove, P.; Capozzi, V.; Garofalo, C.; Rieu, A.; Spano, G.; Fiocco, D. Inactivation of the FtsH Gene of Lactobacillus plantarum WCFS1: Effects on Growth, Stress Tolerance, Cell Surface Properties and Biofilm Formation. Microbiol. Res. 2012, 167, 187-193. [CrossRef] 
48. Heunis, T.; Deane, S.; Smit, S.; Dicks, L.M.T. Proteomic Profiling of the Acid Stress Response in Lactobacillus plantarum 423. J. Proteome Res. 2014, 13, 4028-4039. [CrossRef]

49. Mizrahi, I.; Biran, D.; Ron, E.Z. Involvement of the Pta-AckA Pathway in Protein Folding and Aggregation. Res. Microbiol. 2009, 160, 80-84. [CrossRef]

50. Zhai, Z.; Douillard, F.P.; An, H.; Wang, G.; Guo, X.; Luo, Y.; Hao, Y. Proteomic Characterization of the Acid Tolerance Response in Lactobacillus delbrueckii Subsp. bulgaricus CAUH1 and Functional Identification of a Novel Acid Stress-Related Transcriptional Regulator Ldb0677. Environ. Microbiol. 2014, 16, 1524-1537. [CrossRef]

51. Hamon, E.; Horvatovich, P.; Bisch, M.; Bringel, F.; Marchioni, E.; Aoudé-Werner, D.; Ennahar, S. Investigation of Biomarkers of Bile Tolerance in Lactobacillus casei Using Comparative Proteomics. J. Proteome Res. 2012, 11, 109-118. [CrossRef] [PubMed]

52. Lv, L.-X.; Yan, R.; Shi, H.-Y.; Shi, D.; Fang, D.-Q.; Jiang, H.-Y.; Wu, W.-R.; Guo, F.-F.; Jiang, X.-W.; Gu, S.-L.; et al. Integrated Transcriptomic and Proteomic Analysis of the Bile Stress Response in Probiotic Lactobacillus salivarius LI01. J. Proteom. 2017, 150, 216-229. [CrossRef] [PubMed]

53. Wall, T.; Båth, K.; Britton, R.A.; Jonsson, H.; Versalovic, J.; Roos, S. The Early Response to Acid Shock in Lactobacillus reuteri Involves the ClpL Chaperone and a Putative Cell Wall-Altering Esterase. Appl. Environ. Microbiol. 2007, 73, 3924-3935. [CrossRef] [PubMed]

54. Whitehead, K.; Versalovic, J.; Roos, S.; Britton, R.A. Genomic and Genetic Characterization of the Bile Stress Response of Probiotic Lactobacillus reuteri ATCC 55730. Appl. Environ. Microbiol. 2008, 74, 1812-1819. [CrossRef] [PubMed]

55. Couto, N.; Wood, J.; Barber, J. The Role of Glutathione Reductase and Related Enzymes on Cellular Redox Homoeostasis Network. Free Radic. Biol. Med. 2016, 95, 27-42. [CrossRef] [PubMed]

56. Serrano, L.M.; Molenaar, D.; Wels, M.; Teusink, B.; Bron, P.A.; de Vos, W.M.; Smid, E.J. Thioredoxin Reductase Is a Key Factor in the Oxidative Stress Response of Lactobacillus plantarum WCFS1. Microb. Cell Factories 2007, 6, 29. [CrossRef]

57. Zhang, Y.; Li, Y. Engineering the Antioxidative Properties of Lactic Acid Bacteria for Improving Its Robustness. Curr. Opin. Biotechnol. 2013, 24, 142-147. [CrossRef]

58. Koskenniemi, K.; Laakso, K.; Koponen, J.; Kankainen, M.; Greco, D.; Auvinen, P.; Savijoki, K.; Nyman, T.A.; Surakka, A.; Salusjärvi, T.; et al. Proteomics and Transcriptomics Characterization of Bile Stress Response in Probiotic Lactobacillus rhamnosus GG. Mol. Cell. Proteom. 2011, 10, S1-S18. [CrossRef]

59. Pasqua, M.; Grossi, M.; Zennaro, A.; Fanelli, G.; Micheli, G.; Barras, F.; Colonna, B.; Prosseda, G. The Varied Role of Efflux Pumps of the MFS Family in the Interplay of Bacteria with Animal and Plant Cells. Microorganisms 2019, 7, 285. [CrossRef]

60. Wang, G.; Li, D.; Ma, X.; An, H.; Zhai, Z.; Ren, F.; Hao, Y. Functional Role of OppA Encoding an Oligopeptide-Binding Protein from Lactobacillus salivarius Ren in Bile Tolerance. J. Ind. Microbiol. Biotechnol. 2015, 42, 1167-1174. [CrossRef]

61. Castro-Bravo, N.; Wells, J.M.; Margolles, A.; Ruas-Madiedo, P. Interactions of Surface Exopolysaccharides from Bifidobacterium and Lactobacillus Within the Intestinal Environment. Front. Microbiol. 2018, 9, 2426. [CrossRef] [PubMed]

62. Caggianiello, G.; Kleerebezem, M.; Spano, G. Exopolysaccharides Produced by Lactic Acid Bacteria: From Health-Promoting Benefits to Stress Tolerance Mechanisms. Appl. Microbiol. Biotechnol. 2016, 100, 3877-3886. [CrossRef] [PubMed]

63. Walter, J.; Loach, D.M.; Alqumber, M.; Rockel, C.; Hermann, C.; Pfitzenmaier, M.; Tannock, G.W. D-Alanyl Ester Depletion of Teichoic Acids in Lactobacillus reuteri 100-23 Results in Impaired Colonization of the Mouse Gastrointestinal Tract. Environ. Microbiol. 2007, 9, 1750-1760. [CrossRef] [PubMed]

64. Walter, J.; Schwab, C.; Loach, D.M.; Gänzle, M.G.; Tannock, G.W. Glucosyltransferase A (GtfA) and Inulosucrase (Inu) of Lactobacillus reuteri TMW1.106 Contribute to Cell Aggregation, in Vitro Biofilm Formation, and Colonization of the Mouse Gastrointestinal Tract. Microbiology 2008, 154, 72-80. [CrossRef]

65. Hevia, A.; Martínez, N.; Ladero, V.; Alvarez, M.A.; Margolles, A.; Sánchez, B. An Extracellular Serine/Threonine-Rich Protein from Lactobacillus plantarum NCIMB 8826 Is a Novel Aggregation-Promoting Factor with Affinity to Mucin. Appl. Environ. Microbiol. 2013, 79, 6059-6066. [CrossRef]

66. Ventura, M.; Jankovic, I.; Walker, D.C.; Pridmore, R.D.; Zink, R. Identification and Characterization of Novel Surface Proteins in Lactobacillus johnsonii and Lactobacillus gasseri. Appl. Environ. Microbiol. 2002, 68, 6172-6181. [CrossRef]

67. Goh, Y.J.; Klaenhammer, T.R. Functional Roles of Aggregation-Promoting-Like Factor in Stress Tolerance and Adherence of Lactobacillus acidophilus NCFM. Appl. Environ. Microbiol. 2010, 76, 5005-5012. [CrossRef]

68. Nishiyama, K.; Nakazato, A.; Ueno, S.; Seto, Y.; Kakuda, T.; Takai, S.; Yamamoto, Y.; Mukai, T. Cell Surface-Associated AggregationPromoting Factor from Lactobacillus gasseri SBT2055 Facilitates Host Colonization and Competitive Exclusion of Campylobacter jejuni. Mol. Microbiol. 2015, 98, 712-726. [CrossRef]

69. Castaldo, C.; Vastano, V.; Siciliano, R.; Candela, M.; Vici, M.; Muscariello, L.; Marasco, R.; Sacco, M. Surface Displaced Alfa-Enolase of Lactobacillus plantarum Is a Fibronectin Binding Protein. Microb. Cell Factories 2009, 8, 14. [CrossRef]

70. Monteagudo-Mera, A.; Rastall, R.A.; Gibson, G.R.; Charalampopoulos, D.; Chatzifragkou, A. Adhesion Mechanisms Mediated by Probiotics and Prebiotics and Their Potential Impact on Human Health. Appl. Microbiol. Biotechnol. 2019, 103, 6463-6472. [CrossRef]

71. Salzillo, M.; Vastano, V.; Capri, U.; Muscariello, L.; Sacco, M.; Marasco, R. Identification and Characterization of Enolase as a Collagen-Binding Protein in Lactobacillus plantarum. J. Basic Microbiol. 2015, 55, 890-897. [CrossRef] [PubMed] 
72. Miyoshi, Y.; Okada, S.; Uchimura, T.; Satoh, E. A Mucus Adhesion Promoting Protein, MapA, Mediates the Adhesion of Lactobacillus reuteri to Caco-2 Human Intestinal Epithelial Cells. Biosci. Biotechnol. Biochem. 2006, 70, 1622-1628. [CrossRef] [PubMed]

73. Jia, B.; Raphenya, A.R.; Alcock, B.; Waglechner, N.; Guo, P.; Tsang, K.K.; Lago, B.A.; Dave, B.M.; Pereira, S.; Sharma, A.N.; et al. CARD 2017: Expansion and Model-Centric Curation of the Comprehensive Antibiotic Resistance Database. Nucleic Acids Res. 2017, 45, D566-D573. [CrossRef] [PubMed]

74. Douillard, F.P.; Mora, D.; Eijlander, R.T.; Wels, M.; de Vos, W.M. Comparative Genomic Analysis of the Multispecies ProbioticMarketed Product VSL\#3. PLoS ONE 2018, 13, e0192452. [CrossRef]

75. Liu, B.; Zheng, D.; Jin, Q.; Chen, L.; Yang, J. VFDB 2019: A Comparative Pathogenomic Platform with an Interactive Web Interface. Nucleic Acids Res. 2019, 47, D687-D692. [CrossRef] [PubMed]

76. Malberg Tetzschner, A.M.; Johnson, J.R.; Johnston, B.D.; Lund, O.; Scheutz, F. In Silico Genotyping of Escherichia coli Isolates for Extraintestinal Virulence Genes by Use of Whole-Genome Sequencing Data. J. Clin. Microbiol. 2020, 58, e01269-20. [CrossRef] [PubMed]

77. Zheng, J.; Wittouck, S.; Salvetti, E.; Franz, C.M.A.P.; Harris, H.M.B.; Mattarelli, P.; O’Toole, P.W.; Pot, B.; Vandamme, P.; Walter, J.; et al. A Taxonomic Note on the Genus Lactobacillus: Description of 23 Novel Genera, Emended Description of the Genus Lactobacillus Beijerinck 1901, and Union of Lactobacillaceae and Leuconostocaceae. Int. J. Syst. Evol. Microbiol. 2020, 70, $2782-2858$. [CrossRef]

78. Altermann, E.; Russell, W.M.; Azcarate-Peril, M.A.; Barrangou, R.; Buck, B.L.; McAuliffe, O.; Souther, N.; Dobson, A.; Duong, T.; Callanan, M.; et al. Complete Genome Sequence of the Probiotic Lactic Acid Bacterium Lactobacillus acidophilus NCFM. Proc. Natl. Acad. Sci. USA 2005, 102, 3906-3912. [CrossRef]

79. Pridmore, R.D.; Berger, B.; Desiere, F.; Vilanova, D.; Barretto, C.; Pittet, A.-C.; Zwahlen, M.-C.; Rouvet, M.; Altermann, E.; Barrangou, R.; et al. The Genome Sequence of the Probiotic Intestinal Bacterium Lactobacillus johnsonii NCC 533. Proc. Natl. Acad. Sci. USA 2004, 101, 2512-2517. [CrossRef]

80. Li, P.; Li, X.; Gu, Q.; Lou, X.; Zhang, X.; Song, D.; Zhang, C. Comparative Genomic Analysis of Lactobacillus plantarum ZJ316 Reveals Its Genetic Adaptation and Potential Probiotic Profiles. J. Zhejiang Univ. Sci. B 2016, 17, 569-579. [CrossRef]

81. MetaHIT Consortium; Qin, J.; Li, R.; Raes, J.; Arumugam, M.; Burgdorf, K.S.; Manichanh, C.; Nielsen, T.; Pons, N.; Levenez, F.; et al. A Human Gut Microbial Gene Catalogue Established by Metagenomic Sequencing. Nature 2010, 464, 59-65. [CrossRef] [PubMed]

82. Bustos, A.Y.; Font de Valdez, G.; Fadda, S.; Taranto, M.P. New Insights into Bacterial Bile Resistance Mechanisms: The Role of Bile Salt Hydrolase and Its Impact on Human Health. Food Res. Int. 2018, 112, 250-262. [CrossRef] [PubMed]

83. Begley, M.; Hill, C.; Gahan, C.G.M. Bile Salt Hydrolase Activity in Probiotics. Appl. Environ. Microbiol. 2006, $72,1729-1738$. [CrossRef] [PubMed]

84. O'Flaherty, S.; Briner Crawley, A.; Theriot, C.M.; Barrangou, R. The Lactobacillus Bile Salt Hydrolase Repertoire Reveals NicheSpecific Adaptation. mSphere 2018, 3, e00140-18. [CrossRef] [PubMed]

85. Horackova, S.; Vesela, K.; Klojdova, I.; Bercikova, M.; Plockova, M. Bile Salt Hydrolase Activity, Growth Characteristics and Surface Properties in Lactobacillus acidophilus. Eur. Food Res. Technol. 2020, 246, 1627-1636. [CrossRef] 